\title{
Non-invasive assessment of endothelial function - a review of available methods
}

\section{Corresponding author:}

Julia M. Umińska, Department of Geriatrics, Nicolaus Copernicus University in Torun, Ludwik Rydygier Collegium Medicum in Bydgoszcz, Poland, e-mail: julia.uminska@cm.umk.pl

Medical Research Journal 2021 Volume 6, Number 1, 53-58 10.5603/MRJ.a2021.0008 Copyright (C) 2021 Via Medica ISSN 2451-2591 e-ISSN 2451-4101

\begin{abstract}
The key role of the endothelium in vascular-dependent diseases led to an increase in scientific interest in examining the endothelial function as a tool for screening, as well as for monitoring of the disease and its treatment. In the period from 2016 till 2019, a high level of scientific interest in the assessment of endothelial function has been observed, as expressed in the number of published clinical trials between 369 and 477 per year with the total number of subjects between 49,634 and 75,934.

Currently, none of the known methods of assessing vascular endothelial function is widely used in clinical practice. This may be a result of various factors: scientific (lack of standardization in terms of quantitative indicators of endothelial function), formal (lack of official recommendations for endothelial assessment), financial (the best-validated methods and devices are costly, which renders it unsustainable to use them in screening diagnostics) and technological (high susceptibility of many measurement methods to errors). Nevertheless, it can be expected that non-invasive methods for the early detection of endothelial dysfunction in screening programs will gradually gain importance.
\end{abstract}

Key words: endothelium, endothelial function, endothelial assessment

Med Res J 2021; 6 (1): 53-58

\section{Introduction}

Endothelial dysfunction precedes the appearance of atherosclerotic lesions and their clinical symptoms. Early pathology detection allows the implementation of adequate preventive treatment [1-6]. The study aimed to review non-invasive methods of endothelial function assessment as an attractive option for early diagnosis and an interesting research area.

\section{Endothelial function assessment - general assumptions}

The vast majority of non-invasive methods for endothelial function assessment are based on the phenomenon of reactive hyperaemia. The flow-mediated dilation (FMD) method is based on the ability of endothelium cells to regulate peripheral resistance, while endothelial dysfunction is defined as the impairment of vasodilation due to the secretion of endothelium-derived relaxing factor EDRF [7-10]. The identification of EDRF as nitric oxide (NO) was awarded the Nobel Prize in 1998 [11, 12].

Among the factors modulating the vascular endothelium function, shear stress is the most convenient to apply in clinical practice. The sudden change of shear stress leads to the reactive hyperaemia commonly used in non-invasive tests of the endothelium. The post-occlusion reactive hyperaemia $(\mathrm{PORH})$ is defined as an increase in blood flow following the artery occlusion due to EDRF release $[13,14]$. While not all details of the mechanism of reactive hyperaemia have been established so far, a general pattern can be drawn in the form of a cause-and-effect sequence following the artery occlusion (i.e., deflation of the occlusive cuff). The decrease in peripheral resistance due to vasodilation of the arterioles causes an analogous blood flow increase in the conduit arteries. An increase in blood flow causes a proportional increase in shear forces, and this directly induces endothelial cell mechanoreception pathways resulting in the increased secretion of nitric oxide, which, in turn, causes vasodilation of the conduit arteries $[15,16]$. 


\section{Application of endothelial function assessment in clinical studies}

The key role of the endothelium in vascular-dependent diseases has led to an increase in scientific interest in examining the endothelial function as a tool for screening, as well as for monitoring of the disease and its treatment [13-16]. Apart from the already existing atherosclerosis, the functioning of the vascular endothelium is influenced by, among others:

- Arterial hypertension,

- Hyperlipidaemia,

- Diabetes mellitus,

- Hyperhomocysteinaemia,

- Heart failure,

- Tobacco smoking,

- Age,

- Inflammatory factors,

- Menopause $[1,2,17]$.

Recently, a considerable number of studies applying endothelial function assessment as a research tool have been published. The authors conducted a search covering the period from 1st January 2016 to 31 st December 2020 using the MEDLINE database with "endothelial function" as the only keyword. The initial search revealed 61,399 records. Only 1,873 of those articles, classified as clinical trials, were included for further analysis. References of those studies were searched manually for studies in which endothelial function was assessed. The final analysis comprised 1,742 studies in which several subjects who underwent endothelial function assessment was reported. For each eligible study, the number of studied subjects was defined (Tab. 1).

In the period from 2016 till 2019, a high level of scientific interest in the assessment of endothelial function has been observed, as expressed in the number of published clinical trials between 369 and 477 per year with the total number of subjects between 49,634 and 75,934 . The sudden decline in the number of published studies and the total number of participants seen in 2020 is likely an effect of the COVID-19 pandemic. Therefore, a further increase in the number of such studies should be assumed once the restrictions are eased. It should be emphasized that the performed analysis was limited using only one keyword in one of the most prestigious databases, which groups only the best scientific journals and the yet impressive total number of 262,218 people who underwent assessment of endothelial function was reported. Thus, the actual number of endothelial function tests carried out in the analysed period might have been much higher.

\section{Methods of endothelial function assessment}

Understanding the importance, and thus the growing interest in endothelial pathophysiology has led to the development of several methods for invasive or non-invasive, quantitative evaluation of its function [1-4]. Most of these methods are based on the assumptions: that firstly certain types of stimulation trigger the nitric oxide production leading to local vasodilation, and secondly endothelial dysfunction is a systemic disorder, therefore can be tested in any arterial vessels, most often on easily accessible arteries of the upper limbs [18]. To determine the severity of the endothelial reaction the baseline (reference level) of the assessed parameter should be defined as a reference to its value after the stimulation. Some methods need to employ additional mathematical methods to compensate for the effects of extra-endothelial factors that may interfere with the measurement of the local response [19].

\section{In-vitro methods}

The in-vitro methods of endothelial function assessment are based on the analysis of the concentration of the vasoactive factor in the plasma. Direct measurement of NO concentration is not feasible in everyday clinical practice, and the available techniques are burdened with a considerable error. However, it is possible to assess the concentration of other substances functionally related to the endothelium $[1,2,17]$. The most commonly used markers of endothelial function include:

Table 1. Trials applying endothelial function assessment

\begin{tabular}{lccc}
\hline Year & $\begin{array}{c}\text { Number } \\
\text { of clinical trials }\end{array}$ & $\begin{array}{c}\text { Number of clinical trials } \\
\text { reporting of number } \\
\text { of participants }\end{array}$ & $\begin{array}{c}\text { Number } \\
\text { of participants }\end{array}$ \\
\hline 2016 & 477 & 434 & 75,934 \\
2017 & 432 & 399 & 54,673 \\
2018 & 369 & 352 & 50,095 \\
2019 & 400 & 374 & 49,634 \\
2020 & 195 & 183 & 31,882 \\
Total: & 1,873 & 1,742 & 262,218 \\
\hline
\end{tabular}


- Von Willebrand factor,

- Thrombomodulin,

- Intercellular adhesive molecule (ICAM-1),

- Vascular adhesive molecule (VCAM-1),

- Plasminogen inhibitor type 1 (PAl-1),

- P-selectin and E-selectin,

- Vascular endothelial growth factor (VEGF) $[1,2,10,17]$. Another in-vitro test showing damage to the vascular endothelium may be a measurement of the number of circulating endothelial cells (CEC) in the blood. The increase of CEC correlates with other endothelial markers, including von Willebrand factor, E-selectin and thrombomodulin $[1,2,4-6,10]$.

\section{Invasive in-vivo methods}

Invasive methods of endothelial function assessment are mainly used in scientific research due to the significant risk of complications resulting from the specificity of endovascular procedures [9, 14]. The use of invasive techniques was necessary to establish a reference standard for the validation of completely safe non-invasive methods. Assessment of coronary response to local acetylcholine injection introduced in the 1990 s is a widely accepted method. Vasoconstriction caused by endothelial dysfunction is recorded indirectly by measuring the coronary flow with an endovascular Doppler probe or with thermodilution. The measure of the coronary arteries lumen with quantitative angiography is an alternative to the coronary flow assessment [20]. A positron emission tomography (PET) scanner [22] and magnetic resonance imaging (MRI) with phase contrast [21] were also used to quantify the hyperaemic response to the administration of vasoactive agents.

\section{Non-invasive in-vivo methods}

\section{Flow-mediated skin fluorescence (FMSF)}

One of the non-invasive methods of endothelial function assessment is the measurement of fluorescence [23]. The FMSF is based on the fluorescence measurement of the reduced form of nicotinamide adenine dinucleotide (NADH), emitted by the skin cells in the band of 420 to $480 \mathrm{~nm}$ (peak emission in the range $455-465 \mathrm{~nm}$ ) in response to excitation by UV light in the 300 to $400 \mathrm{~nm}$ range (recommended range is $345-355 \mathrm{~nm}$ ). The test consists of three phases: recording the baseline intensity of the fluorescence (usually 1-2 minutes); occlusion phase (usually 5 minutes); registration of the response (decay of the NADH fluorescence intensity to the baseline, time - up to 15 minutes) [23]. FMSF allows determining the tissues and vascular bed response during ischaemia, while the classic techniques based on FMD are based on a vasomotor reactivity examination [24].

\section{FMD-based methods}

The phenomenon of reactive hyperaemia is the methodological foundation for almost all currently used non-invasive techniques for endothelial function assessment. This group of methods is derived from the classic technique based on the use of ultrasound for direct visualization of brachial artery dilation, which is associated with operator-dependent bias. Therefore, intensive research is conducted on the development of semi-automatic or fully automatic techniques, i.e., techniques that do not require the active participation of the operator during the test.

\section{Classic FMD method}

The classic FMD method assessing the intensity of reactive hyperaemia consists of three phases: measurement of the diameter of a selected artery (e.g., brachial); stimulation phase; measurement after stimulation. As a stimulation, transient ischaemia caused by tightening the sphygmomanometric cuff (by inflating it to pressure 30 to $50 \mathrm{mmHg}$ higher than the baseline systolic blood pressure), is usually applied [9-12,16, 22, 25]. Only a few publications have reported the use of intra-arterial injection of a vasoactive agent: nitro-glycerine [16], acetylcholine or methacholine [9-11, 26]. The relative change in vessel diameter is rather small, assuming values ranging from a few to several per cent compared to the pre-occlusion measurement $[14,16,25]$.

\section{Reactive hyperaemia peripheral arterial tonometry (RH-PAT)}

RH-PAT - a modified FMD method is used in the EndoPAT device (Itamar Medical Ltd.) [27-30]. This method uses finger probes with a two-compartment pneumatic cuff. The proximal cuff is pumped up to a pressure close to the diastolic blood pressure of the patient, and its task is to relieve the arteries walls and reduce the volume of venous blood in the area of the second phalanx of the examined finger [27]. The distal cuff, separately connected to the measurement system, is used for the actual measurement by pneumatic plethysmography. The method has been extensively validated in many publications as a diagnostic and predictive tool in terms of vascular risk assessment [27-32].

\section{Thermal method}

The thermal method used in VENDYS devices (Endothelix Inc.) is based on recording the temperature of two fingers (e.g., index fingers), with one used as a reference, and the other stimulated with a classic 5-minute occlusion with an automatically pumped cuff [33]. The tightening of the cuff causes a decrease in the occluded limb's skin temperature in comparison to the baseline temperature recorded before cuff inflation. Based on the rate of the temperature decay and with the use of 
a mathematical model, a zero-reactivity curve (ZRC) is determined. The third segment of the temperature curve recorded after the restoration of perfusion refers to the ZRC line and normalized to the reference record from the unoccluded (reference) limb. Based on the record from the third phase of measurement, a curve of the hyperaemic response is drawn [33]. The peak temperature, defined as the maximum point of this curve, represents the Vascular Reactivity Index (VRI) [33, 34].

\section{Enclosed-zone FMD (EZ-FMD) method}

This method is based on the oscillometric blood pressure measurement, where the cuff inflation and deflation cycle is repeated six times: at the beginning of the measurement (once) to determine the patient's maximum pulse amplitude and five times after a 5-minute of a total occlusion. The EZ-FMD coefficient is calculated from the formula based on the maximum systolic peak in the pre-occlusion phase and the highest peak in the post-occlusion phase [35, 36].

\section{Photoplethysmography method - reactive}

hyperemia peripheral arterial volume (RH-PAV)

Classic pulse oximetry sensors in the form of finger clips can also be used to test endothelial function. A LED diode operating in the near-infrared region $(940 \mathrm{~nm})$ is used for the test. The methodology of calculating the result is analogous to that of the RH-PAT index: the average amplitudes are calculated from two signal intervals recorded: $40 \mathrm{~s}$ before occlusion and $40 \mathrm{~s}$ after cuff deflation. The results are normalized to the opposite non-occluded limb. The authors of the described technique called it RH-PAV [37].

\section{Impedance plethysmography method}

Impedance plethysmography uses changes in the electrical impedance of tissues caused by pulsatile blood flow. For reactive hyperaemia studies, local injection of acetylcholine or methacholine directly into one of the forearm arteries was used [21].

\section{Laser speckle contrast imaging (LSCI) method}

$\mathrm{LSCl}$ is based on the analysis of speckle pattern images, formed when illuminating the patient's skin surface with laser light. LSCI allows for two-dimensional visualization of peripheral perfusion in the form of a colour map. This method was used to acquire images of perfusion changes occurring under the influence of acetylcholine and in response to classical stimulation with temporary artery occlusion [38, 39].

\section{Laser Doppler flowmetry (LDF) method}

LDF is used to assess peripheral microcirculation, including the measurement of reactive hyperaemia. With regard to vascular endothelial studies, the LDF method is used to assess reactive hyperaemia in the vascular bed of cutaneous vessels. Laser flow meters are well suited for recording the early component of the hyperaemic response associated with rapid dilation of resistance-type vessels (skin arterioles) [41, 42].

\section{Pulse velocity wave (PVW) measurement method}

This method is based on the measurement of the delay of the peak of the peripheral pulse wave, usually in relation to the QRS complex in a simultaneously recorded ECG - the greater the stiffness of the vessels, the faster the pulse wave propagation is observed [43].

The delay is calculated from measurements taken at two different points of the body, such as the carotid and femoral arteries. This technique can also be used for endothelial studies [44]. Depending on the adopted pulse wave recording points, it is possible not only to study the central arterial stiffness but also the peripheral regardless of the condition of the aorta. The stiffness of the arterial wall depends on the vessel ultrastructure, blood pressure and tone of the vascular muscle layer, all varying with age. The use of pulse wave velocity measurement in endothelial studies is based on the assumption that the administration of vasodilators to the patient allows the extraction of the last of these components. Available studies showed a negative correlation between PWV values and endothelial function [43, 44].

\section{Pulse wave analysis (PWA) method}

PWA is based on the mathematical decomposition of the pulse waveform recorded on the peripheral (usually radial) artery. Based on the relation of the timing and the amplitude data several parameters reflecting different aspects of central haemodynamics are determined. Similarly to the PWV technique, the pulse wave analysis may also be supported by pharmacological stimulation to determine the range of vascular endothelium response to the administration of vasoactive agents $[44,45]$.

\section{Summary}

Endothelial dysfunction playing a pivotal role in the pathophysiology of several civilization diseases can be detected at the asymptomatic stage. Therefore, a non-invasive assessment of endothelial function can be applied for early screening in people at increased cardiovascular risk. Moreover, endothelial function assessment can be used as a method for evaluation of treatment effectiveness, as well as for adherence to treatment [46-57]. However, until now these methods have usually been used only for research purposes, and their potential clinical application should be preceded by clinical trials. 
Recent studies indicate the endothelium as the main target of SARS-CoV-2, which often causes thrombotic complications [58-60]. Therefore, studies aimed to assess the usefulness of testing the endothelial function also seem advisable in patients with COVID 19.

Currently, none of the known methods of assessing vascular endothelial function is widely used in clinical practice. This may be a result of various factors: scientific (lack of standardization in terms of quantitative indicators of endothelial function), formal (lack of official recommendations for endothelial assessment), financial (the best-validated methods and devices are costly, which renders it unsustainable to use them in screening diagnostics) and technological (high susceptibility of many measurement methods to errors).

Nevertheless, it can be expected that non-invasive methods for the early detection of endothelial dysfunction in screening programs will gradually gain importance.

\section{References}

1. Obońska K, Grąbczewska Z, Fisz J. Ocena czynności śródbłonka naczyniowego - gdzie jesteśmy, dokąd zmierzamy? Folia Cardiologica Excerpta. 2010; 5: 292-297.

2. Obońska K, Grąbczewska Z, Fisz J, et al. , Cukrzyca i dysfunkcja śródbłonka - krótkie spojrzenie na złożony problem, Folia Cardiologica Excerpta. 2011; 6: 109-116.

3. Koziński M, Kubica J. [Inflammatory response after coronary angioplasty — mechanisms and significance]. Kardiol Pol. 2006; 64(7): 771-4 author reply 775, indexed in Pubmed: 16886140.

4. Grabczewska Z, Kubica J. In search of understanding the endothelium. Cardiol J. 2008; 15(4): 229-232, indexed in Pubmed: 18698537.

5. Grabczewska Z, Thews M, Góralczyk K, et al. Endothelial function in patients with chest pain and normal coronary angiograms. Kardiol Pol. 2007; 65(10): 1199-206; discussion 1207, indexed in Pubmed: 17979048

6. Lampka M, Grąbczewska Z, Jendryczka-Maćkiewicz E, et al. Circulating endothelial cells in coronary artery disease. Kardiol Pol. 2010 68(10): 1100-1105, indexed in Pubmed: 20967702.

7. dela Paz NG, D'Amore PA. Arterial versus venous endothelial cells. Cell Tissue Res. 2009; 335(1): 5-16, doi: 10.1007/s00441-008-0706-5, indexed in Pubmed: 18972135.

8. Chatzizisis YS, Coskun AU, Jonas M, et al. Role of endothelial shear stress in the natural history of coronary atherosclerosis and vascular remodeling: molecular, cellular, and vascular behavior. J Am Coll Cardiol. 2007; 49(25): 2379-2393, doi: 10.1016/j.jacc.2007.02.059, indexed in Pubmed: 17599600.

9. Anderson T. Assessment and treatment of endothelial dysfunction in humans. Journal of the American College of Cardiology. 1999; 34(3) 631-638, doi: 10.1016/s0735-1097(99)00259-4

10. Furchgott RF, Cherry PD, Zawadzki JV, et al. Endothelial Cells as Mediators of Vasodilation of Arteries. Journal of Cardiovascular Pharmacology. 1984; 6: S336-S343, doi: 10.1097/00005344-198406002-00008.

11. Furchgott RF, Zawadzki JV. The obligatory role of endothelial cells in the relaxation of arterial smooth muscle by acetylcholine. Nature. 1980 288(5789): 373-376, doi: 10.1038/288373a0, indexed in Pubmed: 6253831

12. Furchgott R. Endothelium-Derived Relaxing Factor: Discovery, Early Studies, and Identification as Nitric Oxide. Bioscience Reports. 1999; 19(4): 235-251, doi: 10.1023/a:1020537506008.

13. Lorenzo S, Minson CT. Human cutaneous reactive hyperaemia: role of BKCa channels and sensory nerves. J Physiol. 2007; 585(Pt 1): 295-303, doi: 10.1113/jphysiol.2007.143867, indexed in Pubmed: 17901123

14. Papaioannou TG, Stefanadis C. , Vascular Wall Shear Stress: Basic Principles and Methods, Hellenic J Cardiol. 2005; 46: 9-15.
15. Shahzad KA, Qin Z, Li Y. The roles of focal adhesion and cytoskeleton systems in fluid shear stress-induced endothelial cell response. Biocell 2020; 44(2): 137-145, doi: 10.32604/biocell.2020.08500.

16. Inoue T, Matsuoka H, Higashi $Y$, et al. Flow-Mediated Vasodilation as a Diagnostic Modality for Vascular Failure. Hypertension Research. 2008; 31(12): 2105-2113, doi: 10.1291/hypres.31.2105.

17. Goch A, Goch JH. , Wybrane parametry funkcji śródbłonka u chorych na niepowikłane nadciśnienie tẹtnicze z czynnikami ryzyka miażdżycy oraz bez nich, Nadciśnienie Tętnicze. 2005; 9: 118-125.

18. Atzeni F, Sarzi-Puttini P, Sitia S, et al. From endothelial dysfunction to atherosclerosis. Autoimmun Rev. 2010; 9(12): 830-834, doi: 10.1016/j. autrev.2010.07.016, indexed in Pubmed: 20678595

19. Lerman A, Zeiher AM. Endothelial function: cardiac events. Circulation 2005; 111(3): 363-368, doi: 10.1161/01.CIR.0000153339.27064.14, indexed in Pubmed: 15668353.

20. Teragawa H, Ueda K, Matsuda K, et al. Relationship between endothelial function in the coronary and brachial arteries. Clin Cardiol. 2005: 28(10): 460-466, doi: 10.1002/clc.4960281004, indexed in Pubmed: 16274093

21. Hadi HAR, Carr CS, AI Suwaidi J. Endothelial dysfunction: cardiovascular risk factors, therapy, and outcome. Vasc Health Risk Manag. 2005; 1(3): 183-198, indexed in Pubmed: 17319104.

22. Foody JM. , Preventive Cardiology: Insights Into the Prevention and Treatment of Cardiovascular Disease, Humana Press, New Jersey. 2006: 253-255.

23. Gębicki J, Marcinek A, Chłopicki S. Sposób określania parametrów do oceny funkcji śródbłonka naczyniowego. Opis patentowy nr PL226889.

24. Tarnawska M, Dorniak K, Kaszubowski M, et al. A pilot study with flow mediated skin fluorescence: A novel device to assess microvascular endothelial function in coronary artery disease. Cardiol J. 2018; 25(1) 120-127, doi: 10.5603/CJ.a2017.0096, indexed in Pubmed: 28840593.

25. Uehata A, Lieberman EH, Gerhard MD. et. al. , Noninvasive assessment of endothelium-dependent flow-mediated dilation of the brachial artery, Vascular Medicine. 1997; 2: 87-92.

26. Ganz P, Vita JA. Testing endothelial vasomotor function: nitric oxide, a multipotent molecule. Circulation. 2003; 108(17): 2049-2053, doi: 10.1161/01.CIR.0000089507.19675.F9, indexed in Pubmed: 14581383

27. Celermajer DS. Reliable endothelial function testing: at our fingertips? Circulation. 2008; 117(19): 2428-2430, doi: 10.1161/CIRCULATIONAHA.108.775155, indexed in Pubmed: 18474821.

28. Goor DA. et. al, Diagnosing medical conditions by monitoring of peripheral arterial tone, opis patentowy nr WO. ; 00: 74551.

29. Schnall RP. , Probe partucularly useful for non-invasive detection of medical conditions, opis patentowy nr WO. ; 01: 03569.

30. Lavie P, Schanll RP, Sheffy J., Method and apparatus for th non-invasive detection of particular sleep-state conditons by monitoring the peripheral vascular system, opis patentowy nr WO. ; 01: 64101.

31. Obońska K, Grąbczewska Z, Koziński M, et al. Assessment of endothelial function in relation to the presence of type 2 diabetes mellitus in patients with prior myocardial infarction: a pilot study using peripheral arterial tonometry, Folia Medica Copernicana. 2014; 2: 42-48.

32. Grabczewska Z, Adamowicz A, Oboñska K, et al. Neither Cyclosporine nor Tacrolimus Deteriorate Endothelial Function in Renal Transplant Recipients Assessed with Reactive Hyperaemia Index. Transplantation Journal. 2012; 94(10S): 892, doi: 10.1097/00007890201211271-01758.

33. Naghavi M, Yen AA, Lin AW. H., Tanaka H., Kleis S., New Indices of Endothelial Function Measured byDigital Thermal Monitoring of Vascular Reactivity: Data from 6084 Patients Registry; International Journal of Vascular Medicine, 2016, Art. : ID.

34. Naghavi M, Yen A, Panthagani D, et al. Methods and apparatus for assessing vascular health, opis patentowy nr WO2015147796A1.

35. Hirano H, Takama R, Matsumoto R, et al. Assessment of Lower-limb Vascular Endothelial Function Based on Enclosed Zone Flow-mediated Dilation. Sci Rep. 2018; 8(1): 9263, doi: 10.1038/s41598-018-27392-3, indexed in Pubmed: 29915185

36. Idei N, Ukawa T, Kajikawa M, et al. A novel noninvasive and simple method for assessment of endothelial function: enclosed zone flow-mediated vasodilation (ezFMD) using an oscillation amplitude measurement. Atherosclerosis. 2013; 229(2): 324-330, doi: 10.1016/j. atherosclerosis.2013.05.016, indexed in Pubmed: 23880183.

37. Si D, Ni L, Wang Y, et al. A new method for the assessment of endothelial function with peripheral arterial volume. BMC Cardiovasc Disord. 2018; 18(1): 81, doi: 10.1186/s12872-018-0821-5, indexed in Pubmed: 29728052.

38. Hellmann M, Dudziak M. Analiza kontrastu obrazu spekli laserowych - nowa metoda oceny mikrokrążenia, Choroby Serca i Naczyń. 2013; 10: 91-94 
39. Cordovil I, Huguenin G, Rosa G, et al. Evaluation of systemic microvascular endothelial function using laser speckle contrast imaging Microvasc Res. 2012; 83(3): 376-379, doi: 10.1016/j.mvr.2012.01.004 indexed in Pubmed: 22326551.

40. Tamura T. Blood Flow Measurement. Comprehensive Biomedical Physics. 2014: 91-105, doi: 10.1016/b978-0-444-53632-7.00511-6.

41. Maga P, Henry BM, Kmiotek EK, et al. Postocclusive Hyperemia Measured with Laser Doppler Flowmetry and Transcutaneous Oxygen Tension in the Diagnosis of Primary Raynaud's Phenomenon: A Prospective, Controlled Study. Biomed Res Int. 2016; 2016: 9645705, doi 10.1155/2016/9645705, indexed in Pubmed: 28101516.

42. Schlager O, Hammer A, Willfort-Ehringer A, et al. Microvascular autoregulation in children and adolescents with type 1 diabetes mellitus. Diabetologia. 2012; 55(6): 1633-1640, doi: 10.1007/s00125-012-2502-8, indexed in Pubmed: 22366881

43. Gurovich AN, Braith RW. Pulse wave analysis and pulse wave velocity techniques: are they ready for the clinic? Hypertens Res. 2011; 34(2): 166-169, doi: 10.1038/hr.2010.217, indexed in Pubmed: 21107336.

44. McEniery CM, Wallace S, Mackenzie IS, et al. Endothelial function is associated with pulse pressure, pulse wave velocity, and augmentation index in healthy humans. Hypertension. 2006; 48(4): 602-608, doi 10.1161/01.HYP.0000239206.64270.5f, indexed in Pubmed: 16940223

45. Idei N, Ukawa T, Kajikawa M, et al. A novel noninvasive and simple method for assessment of endothelial function: enclosed zone flow-mediated vasodilation (ezFMD) using an oscillation amplitude measurement. Atherosclerosis. 2013; 229(2): 324-330, doi: 10.1016/j. atherosclerosis.2013.05.016, indexed in Pubmed: 23880183.

46. Grześk G, Kozinski M, Tantry US, et al. High-dose, but not low-dose, aspirin impairs anticontractile effect of ticagrelor following ADP stimulation in rat tail artery smooth muscle cells. Biomed Res Int. 2013; 2013: 928271, doi: 10.1155/2013/928271, indexed in Pubmed: 23841099.

47. Grzesk G, Kozinski M, Navarese EP, et al. Ticagrelor, but not clopidogre and prasugrel, prevents ADP-induced vascular smooth muscle cell contraction: a placebo-controlled study in rats. Thromb Res. 2012 130(1): 65-69, doi: 10.1016/j.thromres.2011.12.029, indexed in Pubmed: 22265722.

48. Koziński M, Sukiennik A, Sinkiewicz W, et al. [Drug-eluting stent-associated thrombosis: clinical relevance of impaired vessel-wall healing] Postepy Hig Med Dosw (Online). 2008; 62: 185-205, indexed in Pubmed: 18464681.

49. Kosobucka A, Michalski P, Pietrzykowski $Ł$, et al. Adherence to treatment assessed with the Adherence in Chronic Diseases Scale in patients after myocardial infarction. Patient Prefer Adherence. 2018; 12 333-340, doi: 10.2147/PPA.S150435, indexed in Pubmed: 29551891.
50. Kubica A, Kosobucka A, Fabiszak T, et al. Assessment of adherence to medication in patients after myocardial infarction treated with percutaneous coronary intervention. Is there a place for newself-reported questionnaires? Curr Med Res Opin. 2019; 35(2): 341-349, doi: 10.1080/03007995.2018.1510385, indexed in Pubmed: 30091642.

51. Kubica A, Obońska K, Fabiszak T, et al. Adherence to antiplatelet treatment with P2Y12 receptor inhibitors. Is there anything we can do to improve it? A systematic review of randomized trials. Curr Med Res Opin. 2016; 32(8): 1441-1451, doi: 10.1080/03007995.2016.1182901, indexed in Pubmed: 27112628.

52. Kubica A Kasprzak M Siller-Matula J, et al. Time-related changes in determinants of antiplatelet effect of clopidogrel in patients after myocardial infarction. Eur J Pharmacol. 2014; 742: 47-54, doi: 10.1016/j. ejphar.2014.08.009, indexed in Pubmed: 25199965.

53. Pietrzykowski Ł, Michalski P, Kosobucka A, et al. Medication adherence and its determinants in patients after myocardial infarction. Sci Rep. 2020; 10(1): 12028, doi: 10.1038/s41598-020-68915-1, indexed in Pubmed: 32694522

54. Kubica A, Obońska K, Kasprzak M, et al. Prediction of high risk of non-adherence to antiplatelet treatment. Kardiol Pol. 2016; 74(1): 61-67, doi: 10.5603/KP.a2015.0117, indexed in Pubmed: 26101025.

55. Kubica A, Kasprzak M, Obońska K, et al. Discrepancies in assessment of adherence to antiplatelet treatment after myocardial infarction. Pharmacology. 2015; 95(1-2): 50-58, doi: 10.1159/000371392, indexed in Pubmed: 25592409

56. Kubica A, Kosobucka A, Michalski P, et al. Self-reported questionnaires for assessment adherence to treatment in patients with cardiovascular diseases. Medical Research Journal. 2018; 2(4): 115-122, doi: 10.5603/mrj.2017.0015.

57. Kosobucka A, Michalski P, Pietrzykowski $Ł$, et al. The impact of readiness to discharge from hospital on adherence to treatment in patients after myocardial infarction. Cardiol J. 2020 [Epub ahead of print], doi: 10.5603/CJ.a2020.0005, indexed in Pubmed: 32037501

58. Guzik TJ, Mohiddin SA, Dimarco A, et al. COVID-19 and the cardiovascular system: implications for risk assessment, diagnosis, and treatment options. Cardiovasc Res. 2020; 116(10): 1666-1687, doi: 10.1093/cvr/cvaa106, indexed in Pubmed: 32352535.

59. Pons S, Fodil S, Azoulay E, et al. The vascular endothelium: the cornerstone of organ dysfunction in severe SARS-CoV-2 infection. Crit Care. 2020; 24(1): 353, doi: 10.1186/s13054-020-03062-7, indexed in Pubmed: 32546188

60. Navarese EP, Musci RL, Frediani L, et al. Ion channel inhibition against COVID-19: A novel target for clinical investigation. Cardiol J. 2020; 27(4): 421-424, doi: 10.5603/CJ.a2020.0090, indexed in Pubmed: 32643141. 